\title{
NATIONS IN REVIEW(s): MODERNiST “LitTLE” MAGAZINES AND THE (TRANS)NATIONAL IMAGINATION
}

\section{Maria José Florentino Mendes Canelo $Q$}

\begin{abstract}
This article brings together three case-studies of modernist "little" magazines: Orpheu (1915) and Portugal Futurista (1917), in Portugal; Klaxon (1922-1923) and Revista de Antropofagia (1928-1929), in Brazil, and The Seven Arts (I9I6-I9I7), in the United States. The article proposes a comparative analysis of texts published in the magazines with a view to shed light on their contribution to debates on nation building. Besides considering the role of "little" magazines as heralds of new controversial ideas and as springboards for new artists, the essay examines the magazines as microcosms of the cultural and social models under revision in modernist theories and aesthetics. The magazines are ultimately taken as imagined communities that aimed at redefining the borders of the nation and the meanings of national identity by means of new interpretations both of national culture and of the role poets and intellectuals played in it.
\end{abstract}

KEYWORDs: "little" magazines, modernism, nation, transnationalism, Orpheu, Portugal Futurista, Klaxon, Revista de Antropofagia, The Seven Arts

Depois de garantida e administrada a nacionalidade portuguesa por aqueles a quem compita garanti-la e administrá-la, ainda fica por cumprir a melhor parte do programa português: É então que chega a vez dos poetas e criadores do caso português (não o seu caso político mas o seu caso físico) universalmente projectado para dentro e fora das nossas fronteiras.

COMPARATIVE LITERATURE STUdiEs, VOL. 55, NO. 3, 2018.

Copyright (C) 2018. The Pennsylvania State University, University Park, PA. 
(Once the Portuguese nationality has been guaranteed and administered by those responsible for guaranteeing and administering it, the best part of the Portuguese program is yet to be fulfilled: now enter the poets and the creators of the Portuguese case [not the political but the physical case] universally to be projected inside and outside our borders.)

José de Almada Negreiros ${ }^{1}$

\section{Introduction}

AU: insert author and work citation stems from

My epigraph presents a description of the poet's role in shaping the national culture subscribed by one of the leading modernist artists in Portugal, José de Almada Negreiros. His words capture the several aspects on which this study aims to shed new light, from the role of literature in the construction of cultural identity and difference to the national and transnational dimensions of such a project in the context of modernism. Almada Negreiros was a multifaceted artist, who, together with poet Fernando Pessoa, commanded the modernist assault on the Portuguese conformist cultural landscape of the first decades of the twentieth century by means of "little" magazines, thus involving print culture in the political renovation of the nation. In the cited passage above, Almada Negreiros clearly distinguishes two orders regarding nation building - the political and the symbolic - to which culture and literature make a significant contribution. In effect, in the modernist case studies under analysis, it is common for new discourses to build their authority on the connection between culture and politics, aesthetic renovation becoming a spiritual supplement to economic development and political maturity.

However, when stating elsewhere that the "collective administration has a generosity limit for the people it administers," Almada Negreiros touches upon another issue that is crucial to the modernist artistic communities: the homogenizing discourse emanating from the State that threatens to hinder individual expression and creativity, precisely for neglecting "matters of the spirit." ${ }^{2}$ This tension evinces two specific procedures related to the nation-building process that Homi Bhabha defined as pedagogy, that is, the discourse emanating from the center, mainly from the State, and performativity, meaning the discourse of the subjects, ${ }^{3}$ which, in this case, I apply to artistic expression and the emergence of the "little" magazines in particular.

Almada Negreiros's statement suggests that the divide between these two ways of constructing national identity lies at the root of modernist 
aesthetics. As a new form of expression, modernism sought to meet what its intellectual advocates saw as both individual and collective needs, striving for new relationships between the individual and the community, on the one hand, and the individual and the State, on the other. As I argue in the essay, although transnationalism is crucial to the analysis of this cultural formation, the revision of the national form is central to the aesthetic and cultural battles undertaken in the modernist circles and the emergence of the "little" magazines themselves may be one of the outcomes of such struggles.

The assertion of modernism, a minority discourse that, like many others, had to fight for its own voice, corresponded to the emergence of new cultural elites that sought to differentiate themselves by both the innovation of their expression and their contribution to the revision of the project of national identity. Such restructuring was rushed by modernization, which threatened to make national cultures more homogeneous and disregard individual contributions to culture and to emergent forms of mass culture as well, since, as Robert Scholes has remarked, "little" magazines, being noncommercial at heart, posited themselves in a clear opposition to mass magazines. ${ }^{4}$ But my focus here is how the modernist elites intended to revise the forms and meanings for (re)constructing the idea of the nation in particular. I shall analyze how their attempt to negotiate the requirements of modernization, nationalism, and internationalism implied renegotiating also the pedagogical master narrative of nationalism and the intervention of individual, or performative, discourses. I believe the "little" magazines became the performative discursive spaces for such intervention.

Indeed, I suggest that even before imagining a (trans)national community, modernist intellectuals imagined the "little" magazine's project and community as their own source of identification and loyalty. This was the primal space where they could perform their individuality by critically reviewing the national reality. And despite the fact that the modernist canon came to reduce the "little" magazine to a showcase of the future individual geniuses of modernism, ${ }^{5}$ it is my intention here to recover the critical value of the "little" magazine as a collective project in itself. I suggest we perceive the "little" magazines as microcosms of the cultural and social, if not political, models under revision in the aesthetics and theories they published. Along these lines, the "little" magazines provide an intermediate space between the ruling modes for imagining the nation: the pedagogical as the discourse about subjects, constituting them as objects, and the performative as the discourse of the individuals, constituting them subjects. In the magazines' space, the backstage of culture opens up and the readers witness lively debates on what the national identity is, is not, or could be. 
These artists' reconfigurations of national culture were conceived and disseminated by means of literary magazines that often span over a very short period of time. The adjective "little" refers not only to their short duration, but certainly also to their small revenues and readerships, which notwithstanding allowed them to become the heralds of several experimental movements, such as modernism itself. My reading suggests that the so-called "little" magazines in effect challenged the process of national imagination established by Benedict Anderson in Imagined Communities. What strikes one as new is the way "little" magazines interrupted the "homogeneous, empty time" of the nation. Newspapers and novels, in Anderson's argument, allowed their readers to imagine common belonging in the simultaneous act of reading and therefore contributed to consolidate the nation as a horizontal and anonymous community spreading along a common space-time frame, like "a sociological organism moving calendrically."

It is my contention that "little" magazines, precisely because they were the opposite to the forms Anderson enunciates-by definition inherently unstable, hybrid, and discontinuous - challenged the linearity of national space and time. To follow Edward Bishop, they were necessarily "in an adversarial position with regard to the dominant culture" 7 and therefore created spaces for new disruptive ideas that questioned the linear succession underlying the construction of a master narrative of national identity. In other words, form and content united in making them performative tools to develop alternative discourses to that of nationalism and imagine different forms of community. As I will show, the fragmentariness of the genre did not, however, disqualify the "little" magazine as an active agent in the "complex system of literary and critical exchange." I tend to agree with Eric Bulson when he states that the development of the "little" magazine as part of the print culture boom at the beginning of the twentieth century benefitted from "modes of unregulated literary production, free from commercial restraints, but also [enhanced] the construction of a network of writers and readers connected through modern print practices," except that I do not believe the description applies to Euro/Anglo-centric standards alone, as the locations of my case-studies also suggest.

The cultural synthesis proposed in the "little" magazines under study often border on ideas of what has in recent decades been designated as transnationalism, and here I follow Heidi Shukla and Sandhya Tinsman, who define the concept as "a paradigm directly opposed to the bounded and often essentialized 'national histories' of discrete countries, as well as to the central organizing principle of a North-South dichotomy," ${ }^{10}$ which inevitably alters the bonds of identity and also the process of identification to both nation 
and culture. Rather than focusing on the national unit alone, the critics and poets included in this analysis emphasize cultural diversity and hybridity, gradually breaking away with the nationalist tenets of unity, homogeneity, and cohesion. I believe they therefore anticipate a critical perspective that Shelley Fisher Fishkin assigns to the transnational outlook, "that we see the inside and outside, domestic and foreign, national and international, as interpenetrating." 11 It is a worldview that turns the nation into "a participant in a global flow of people, ideas, texts, and products." 12

But because transnationalism does not necessarily do away with the question of location, ${ }^{13}$ my choice of the three case-studies at hand relies on Immanuel Wallerstein's notion of the semiperiphery, ${ }^{14}$ because, from a geopolitical perspective, the three countries involved in this analysis were undergoing circumstances related to deep changes in the world order, redefining centers and peripheries. ${ }^{15}$ The critique of the national framework subscribed to in the "little" magazines reflected the artists' perspectives of both the constrictions and the opportunities implied in the geopolitical changes under way in the first decades of the twentieth century.

In fact, this type of intermediation is noticeable in several dimensions of cultural creation in the three cultural stages under analysis and also in their relationships. While the United States was gaining centrality in the world order, Portugal was in the process of losing its supremacy and this demotion showed in the relationship with other core-countries in Europe and in Brazil, its ex-colony $D$ th Orpheu and Portugal Futurista take strong stances in this debate. Braztr m turn became the space where the switching of influence could be witnessed, as the country gradually moved into the U.S. sphere of influence. Yet, this movement created suspicion among Brazilian neighbors that, by siding with the emerging core-nation (the United States), Brazil intended to act as center within its own region. As I will show, this interstitial condition will emerge rather clearly in the pages of both Klaxon and Revista de Antropofagia. In turn, one of the prime concerns of the U.S. "little" magazine The Seven Arts $^{16}$ was to complement the acknowledged economic and political status the United States had reached with a culture equally powerful.

The "Little" Magazine: Imagining the (Trans)National Community to Come

Concerning Portuguese modernism, both "little" magazines Orpheu and Portugal Futurista were understood by their editors and contributors as stepping stones in a project seeking to undermine the cultural and political 
order. If we look at the social and political instability of the first two decades of the twentieth century, especially the numerous authoritarian coups during that period, it is possible to consider modernist art-and the two previously mentioned magazines - as part and parcel of the social and political unrest of the age. It is a fact that both the third issue of Orpheu and the first (and only) of Portugal Futurista fell victims to censorship.

If we take a closer look at the Portuguese cultural context in the decades prior to the launching of Orpheu, the malaise is evident. Portugal's peripheral status in relation to Great Britain since the episode of the 1890 British Ultimatum, after the Berlin Conference over the partition of Africa amidst the European empires, fuels the artists' rage. It is certainly not accidental that the two most powerful (and violent) texts in Portugal Futurista are formulated as Ultimata. The sense of an inferior or peripheral status is bitterly exposed by Almada Negreiros, in another manifesto styled text, his 1915 "chapbook" "Manifesto Anti-Dantas" ("Anti-Dantas Manifesto"). While reacting directly against those who would not understand Orpheu's innovation, Almada Negreiros also conveyed how the conservative elites contributed to decaying representations of the national identity. In order to eradicate this depiction, the poet urged his fellow citizens to express the Portuguese spirit in all its brilliance, otherwise the nation would remain "A África reclusa dos europeus" (The secluded Africa of the Europeans) or "O paiz mais atrazado da Europa e de todo o mundo! O paiz mais selvagem de todas as Áfricas!" (The most backward country in Europe and the whole world! The wildest country in Africa!)" 17 One way or another, the subjugation exposed by the British Ultimatum lingered in the feeble political affirmation promoted by the recently established republican regime. ${ }^{18}$

Fernando Pessoa and Almada Negreiros interpreted the loss of international sovereignty and the acritical reception of foreign influences as a process of denationalization. As in the writings of the contributors to the "little" magazines The Seven Arts and Revista de Antropofagia, the Portuguese artists believed that this loss of a national character came from a noncritical acceptance of foreign influences and a neglect of the true needs and specificities of Portuguese culture, in this case. That national culture also suffered from the proliferation of materialism and an overall lack of interest in spiritual and artistic matters was part and parcel of their diagnosis.

The adoption of imported cultural and political paradigms created an artificial social model unable to ignite the nation's sensibility and creativity. As a result, these nations were not effectively prepared to react to and accommodate modernization at a moment when they had not yet come to terms with the changes in their geopolitical position in the world order. 
Using arguments quite similar to those employed by The Seven Arts' contributors in regard to the intermediate condition of the United States, Almada Negreiros stated that "os portugueses parece estarem ainda no momento de não suporem a independencia senão quanto à sua nacionalidade, isto é, ainda não supõem a independencia individual portuguesa dentro da independencia da nossa nacionalidade" (it seems the Portuguese are still unable to consider their independence apart from their nationality, that is, they are unable to consider the Portuguese individual independence within the independence of our nationality). ${ }^{19}$ Almada Negreiros was here detecting a significant weakness: the national community was formed by individual cases, whereas the individual consciousness of the nation was a belated construction.

Pessoa elaborated the problem as an interruption, a suspension of national identity: "estavan (n) rrompidos os portugueses" (the Portuguese were interrupted), he originally stated in 1923, in an interview to the magazine Revista Portuguesa. ${ }^{20}$ The nation was suspended. However, the vacuum of authenticity created by denationalization fostered the ideal conditions for a new beginning. In the Portuguese case, it took form in what Pessoa later devised as a refashioning of the old empire into a spiritual enterprise, a form of worldwide cultural expansion he called the "Fifth Empire." ${ }^{21}$ I believe this notion reverberates in that of the ground zero also present in the primitivism of Revista de Antropofagia and The Seven Arts. In effect, the artists sought to enlarge the project of a national identity by enabling it to recombine multiple influences.

The cultural project that began with the "little" magazine Orpheu, in I9I5, was therefore based on a commitment to reconfiguring culture and, consequently, the national identity that had been belittled during the period of political subjugation to Great Britain. By opposing British authority, Pessoa's identity project partially assumes the image of the "other" that had always been ascribed to Portugal by European imperial powers, and turns to a new realm of fulfillment-the Atlantic, building on what Irene Ramalho Santos has called Pessoa's Atlanticism. ${ }^{22}$ However, when the "little" magazine Portugal Futurista was put together, in 1917, the Portuguese identity was asserted by siding with the European tradition again. Almada Negreiros, moved by Portugal's entry in the war, reintegrated the national artistic creation into the old center. Both Almada Negreiros's profoundly antibourgeois attacks and Pessoa/Álvaro de Campos's eviction notice to "the mandarins of Europe," in their respective "Ultimata," in Portugal Futurista, sought to affirm a national difference that the State itself was unable to foster. But what is of interest to me is how this oscillation seems to suggest division and also possibility in new alliances that once again present us with a refashioned proposal of the national idea. 
In Brazil, Klaxon had a similar impact as Orpheu in Portugal. The Brazilian "little" magazine was published in the wake of the Modern Art Week, an event held in 1922, in the most industrialized and developed city in the country, São Paulo. It was intended as a contribution to the celebration of the centennial of the nation's political independence and showcased the nation's advances in cultural terms, namely the experimental writings of young poets such as Mário de Andrade. The Serven Arts was also published in a symptomatic historical moment: I9I6, in New York, during the peak of World War I, and strongly committed to fight U.S. intervention in the war. Likewise, in Portugal, the new order (or the lack of one, if we consider the underlying anarchism in Fernando Pessoa/Álvaro de Campos's "Ultimatum") proposed in Portugal Futurista led to its official banning. In Brazil, a few years after the Modern Art Week event, in 1929, Revista de Antropofagia, which inaugurated the so-called second Brazilian modernism, ended up squeezed into a column in the newspaper Diário de S. Paulo, but it was eventually discontinued because of the readers' protests against the cultural anthropophagists' aggressive and fiery, albeit metaphoric, claims on cannibalism.

The renegotiation of Brazil's position in the new world order can be observed in the magazines themselves, where influence by Portugal or the United States was both summoned and rejected. Klaxon and particularly Revista de Antropofagia allow us to examine the selection of influences concerning the old and the new centers of power. The "first modernism," marked by the Modern Art Week of 1922 and the "little" magazine Klaxon strove to establish a Brazilian Portuguese linguistic standard, which clearly pointed toward a rupture in the relationship with Portugal.

But culture was fundamental to fulfill this emancipation and make Brazil a fair partner in the new world economy. Contributor Menotti del Picchia was aware of that, when stressing the "little" magazine's fundamental propaganda work in promoting Brazil via its artistic talent instead of its economic potential; hence del Picchia's introduction of Klaxon as the "ministro plenipotenciário das letras nacionais junto dos governos culturais de todo o mundo" (plenipotentiary minister of national literature to the cultural governments of the entire world).$^{23}$

Yet, by 1928 , the "second modernism" (the radical movement of cultural cannibalism), would rather focus its criticism on the United States. In this regard, Antônio de Alcantara Machado's anti-imperialist editorials are particularly expressive, as they address not only the former and now decaying metropolis, but also the rising American hegemon, the United States. The editorials of Revista de Antropofagia written under Machado's leadership longed for Brazil to be free to draw on its own culture and identity. 
In the United States, in turn, amidst intellectual circles, there was the awareness that the nation's effective economic centrality was not matched by cultural prominence. Except for the rare cases of Walt Whitman and Henry James in literature, and James Whistler in painting, the nation was yet to find a corresponding central position in the cultural field. It is my belief that the period of entry into the Great War, as illustrated by the "little" magazine The Seven Arts, provides a particularly fertile moment to examine the redefinition of the U.S. position in the world order in the ways The Seven Arts intellectuals discuss the national project. ${ }^{24}$

In a time of hesitation and expectation, the United States was coming to terms with its recently accomplished imperial sovereignty, consolidated by means of its influence on Central and Latin America. Nevertheless, in the artistic and cultural spheres, the excessive influence of Europe was still strong, a legacy of the nation's colonial past. The divided attitudes toward participation in World War I was part of this condition. Whereas for some the war was seen as an opportunity to strengthen the nation's growing political power, for others it resumed to a service to European interests alone. The pacifism of The Seven Arts' contributors shared the latter's viewpoint. In the article "The Collapse of American Strategy," by the most radical and sharpest opponent to the U.S. entry in the war, Randolph Bourne, U.S. involvement was portrayed as a trace of colonial submission to Great Britain. Bourne further signaled the loss of the nation's prior position as a mediator as precisely a loss in sovereignty ${ }^{25}$

Bourne associated the positrur of the United States to the nation's immaturity. In his view, entry into the war blurred the lines between the American course of action and the allies', that is to say, it relinquished American difference. Though aligning his stances with a constructive skepticism ${ }^{26}$ arne was very critical of the financial and strategic interests disguised as trrnocratic intentions $\cap$ e therefore called particular attention to what he assumed to be the manipuration of U.S. interests: "Guarding neutrality, we might have counted toward a speedy and democratic peace. In the war, we are a rudderless nation, to be exploited as the Allies wish, politically and materially, and towed, to their aggrandizement, in any direction which they may desire" क sides exposing colonial wounds, this type of discourse revealed feelings 6 anxiety regarding the national project.

The "little" magazines therefore emerged as the stage in which new modes of relation between the individual and the community could be experimented. Of all the three cases under scrutiny, The Seven Arts was perhaps the broadest in scope, being open to a wider audience and a more diverse range of contributors. Yet, it shared one of the chief concerns of the 
other magazines concerning the elevation of national culture. The magazine was created as a space where a national art could flourish. Indeed, it was a springboard for numerous American writers, who aligned with the magazine's policies, from John dos Passos to H. L. Mencken and Carl Sandburg and, as reminded early on by James Oppenheim, one of its editors-in-chief, "It was the intention of the magazine to call for the best work of our young writers and critics, in the hope that THE SEVEN ARTS might become the nucleus of a greater national consciousness. ${ }^{29}$

But the editors also published prestigious foreign authors when the texts reflected on questions of U.S. identity. An aspect peculiar to The Seven Arts was the fact that its mentor was a French writer, Romain Rolland, who signed the article "America and the Arts," (11)a translation by Waldo Frank. In this article, introduced as one of the foumang texts of the magazine project, the responsibility for the "integrating task," a renewed version of what the Europeans called the "civilizing mission," was passed on to the United States. Rolland argued that, following the model of high culture of the great civilizations of the past, the United States had to recreate its cultural diversity into a harmonious synthesis, what he termed "a symphony."

Because U.S. difference was based on its racial, ethnic, and cultural variety, it ensured the achievement of the highest civilizational goal Europe had failed to accomplish: "the dream of an integrated and entire humanity." ${ }^{1}$ The recombination of cultural elements should therefore originate a new kind of poet or intellectual, someone capable of integrating different cultural aspects. In this regard, Fernando Pessoa/Álvaro de Campos's idea of the "Humanidade dos Engenheiros" (a Humanity of Engineers) announced at the end of the "Ultimatum," in Portugal Futurista, comes to mind bringing together humans and science, the "Humanidade mathemattea perfeita" (a perfect, mathematical Humanity) would be attained. In Pessoa/ Campos's opinion, its human expression would be the "Superhomem" (Superman), further defined as "o mais completo" (the most complete), "o mais complexo" (the most complex), and "o mais harmonico" (the most harmonious). This harmony resulted from the fact that it did not dismiss differences, but instead accepted and encompassed them as differences: "uma harmonia entre as subjectividades alheias (das quaes a propria faz parte)"33 (a harmony in the midst of many subjectivities [one of which will be his]).", The Seven Arts contributors imagined the national community along simil lines but referred to the idea as the "spiritual technique." This consisted of "a living culture" or "a complicated scheme of ideal objectives, upheld by the society at large enabling them to submerge their liberties in their loyalties and to unite in the task of building up a civilization." ${ }^{35}$ Finally, Randolph 
Bourne suggested an alliance between "technique" and "vision," allowing the individual to experience matter through both technique and the senses. ${ }^{36}$

An identical notion also surfaces in Brazilian modernism, namely in Oswald de Andrade's idea of the cultural cannibals as modern primitives, capable of using modern technique in their own interests but defining their identity by feeling, rather than reason. Oswald de Andrade called this humanity-to-come the "bárbaro tecnicizado" (tecnicized barbarian) inspired by the philosophical theories of Hermann von Keyserling, even though undergriding de Andrade's metaphor was the integration of technique (the modern and imported) into an idealized national innocence (the barbarian here reads as the primitive or the native). What Oswald de Andrade ultimately aimed at was an "innocent progress," an integration of modernization that would not erase difference, or did not denationalize the local culture, as the Portuguese modernists might also put it.

In The Seven Arts, Randolph Bourne highlighted the need to invent a kind of intelligence "suffused by feeling" and a feeling whose "fibre and outline [came from the] intelligence." ${ }^{77}$ The idea borders Pessoa's concept of the intellectualized emotion that marks the originality of the individual poet who will renew national culture, in clear opposition to the sentimentalism of the masses. Pessoa gives form to this notion in Álvaro de Campos's "Ultimatum," when he contrasts the emergence of the "Homem-Synthese da Humanidade" 38 (the Synthesis-of-Humanity Man) ${ }^{39}$ to the inferior status of the common man: "Relegação do povo ao seu papel scientificamente natural de mero fixador dos impulsos do momento" 40 (The People's scientifically natural role will be merely to define current impulses). ${ }^{41}$

But the rise of the leading poet, as one of the elites, erased other voices or forms of expression, in this case, other classes. This issue also emerges in the Brazilian and U.S. modernist projects but regarding ethnicity. Harmonization stood as a demonstration of America's ability to offer the world the model for a different community that went beyond inner ethnic differences. The conciliation of differences in the U.S. society and art was the fulfillment of what would be internationalism in the future, the transnation. However, the type of cultural integration proposed by The Seven Arts ultimately silenced dissonance.

In The Seven Arts, the new project focused on reviewing individualism and the role of the poet or intellectual. But the magazine essentially presented itself as a space of total freedom where artists could express their individuality: "What we ask of the writer . . . is that portion of his work which is done out of necessity for his own deep pleasure as a writer" A a guarantee of humanity, individuality gave artists the power to represemt 
their nation at a time when individuality was increasingly threatened by the forms of standardization inherent to mass culture and the pedagogic nationalist discourse.

The organic experience was the new way for the individual to feel and generate meaning to the new project envisaged by The Seven Arts contributors. This was the only option for individuals to participate effectively in their community. Individuals would then evolve from stagnant insignificant pieces as objects of a discourse with which they did not identify, to agents actively constructing meaning for their nation; in Waldo Frank's words, "By art, [man] ... achieves that sense of unity and at-homeness with an exterior world which saves him from becoming a mere pathetic feature of it." ${ }^{43}$ This experience implied returning to a bare mode of expression, enabling the connection between art, critical thinking, and science, as well as the creation of new aesthetic objects. For The Seven Arts intellectuals, this was the essence of a new culture the United States could set as an example to the world. ${ }^{44}$

In line with ideas also entertained by the Brazilian modernists, James Oppenheim called for a retrieval of spirituality, bringing back the primitive side of culture - childlike, emotional, instinctive, naïve, and ignorant ${ }^{4}$ but without dismissing technology. Randolph Bourne added that a return to nature was essential for the individual to catch up with the inevitable technological progress: "They are not barbarians, but seek the vital and the sincere everywhere. All they want is a new orientation of the spirit that shall be modern, an orientation to accompany that technical orientation which is fast coming, and which the war accelerates." ${ }^{46}$

The driving force behind the social utopia idealized by The Seven Arts and its contributors was therefore an "organic individualism," in Van Wyck Brooks's words: "The new individualism ... is individualistic only by default; ... [I]t is not combative, it is coöperative, not opinionative but groping, not sectarian but filled with an intense, confused eagerness to identify itself with the life of the whole people." ${ }^{2}$ enting new communities was an essential part of this project, given ronic formula described by Van Wyck Brooks: a cohesive community, able to unify the different cultural expressions constitutive of the United States. ${ }^{48}$ American culture already had a model for this ideal connection between the individual and the collective offered by the poet Walt Whitman, who had "performed" the necessary relinquishment of the "self" in his engaging and all-encompassing poetry. ${ }^{49}$

Inspired by Whitman, the magazine fostered in its pages a culture of popular inspiration, connected to the people and geared toward the community. The Seven Arts aimed to encourage the creation of a setting where artists could forge an artistic community capable of rebuilding national art. Hence 
the following invitation to prospective contributors: "In all such epochs the arts cease to be private matters; they become not only the expression of the national life but a means to its enhancement." 50

Rejecting massification and ignoring conventions was, in fact, more than an individual duty, it was a political imperative. In James Oppenheim's view, for the artist to be "at the same time, both a citizen and an artist," he had to go beyond the average thi merazine's project, individualism never loses sight of the commu since individuals were guided by a common purpose, their individual expression was the expression of their community, an idea reverberated throughout Oppenheim's statement in The Seven Arts inaugural editorial.

But neither did the project at The Seven Arts dispense with the idea of an intellectual and creative elite. It was shaped as an elite of individuals whom Van Wyck Brooks called "honnêtes gents." 52 is elite was compared to a transmission belt that "linked the artistic expreoron at the top with the common consciousness of the race beneath." ${ }^{3} 3$ Waldo Frank developed Van Wyck Brooks's outline of the desirable elite into a community of what he in turn called "group individuals," ${ }^{4}$ whose model was Jules Romain's idea of unanimism. Frank praised Romain's notion of an organic individualism, according to which the individual's intellectual uniqueness was not diminished or erased by his belonging to a group. Because, from the perspective of the magazine contributors, individualism was a requirement for subjectivity.

Almada Negreiros's theoretical stances are here useful in understanding the same topic in the case of Portuguese modernism. To this artist's mind, it was essential to contrast individuality with community, since the latter tended to be more and more an amorphous mass: it was "materialidade pura" (pure materiality). ${ }^{55}$ If the elite's task at hand was essentially spiritual, then the "little" magazine community was the only one able to counter the nation's excessive materiality. From Almada Negreiros's perspective, the elite was the humanist counterpoint craved by his ideal of society: "A élite é coisa séria, é até a mais séria de todas onde haja um povo; não cuida apenas do governo do povo pois que reconhece já a pessoa humana também. A élite não se resume na ciência política, é sobretudo conhecimento do humano." (The elite is a serious matter, it is actually the most serious one wherever there is a people; it is not limited to governing the people, since it also recognizes the human person. The elite is not restricted to political science, it is mainly concerned with the knowledge of the human). ${ }^{56}$

British philosopher Bertrand Russel's contribution to the final issue of the magazine The Seven Arts, written during the war, comes in line with Rolland's article in the first issue: Russell distinguished the United States 
for its mission and urged it to reinvent the traditional concept of the nation. Russel attacked nationalism as a desire for power. He acknowledged, however, that it was to a good extent necessary but it had to be different from its present version: "I do not deny that there is a kind of nationalism which might be a stimulus to civilization and not a cause of strife. Nations might take pride in what they had added to the common stock rather than in what they had robbed of others." ${ }^{27}$ Difference among nations was precisely what Russell identified as healthy and necessary: "the differentiation of mankind into groups, not necessarily hostile, but distinct one from another in culture and proximate purpose, is a thing of great importance for the diversity and progressiveness of human society. Without it life will have no richness of texture." ${ }^{28}$

Stressing a fundamental aspect for the collective of The Seven Arts, the youthfulness of the United States, Russell concluded that the nation had escaped nationalism because this was a typically European stage of development. Supposedly devoid of all the elements which would normally constitute a nationalist ideology (tradition, settlement, ethnic $\rightarrow$ cultural homogeneity), the United States could devise new patterns or ationship between the individual and the group, new models of sympathy and cohesion, and new forms of relation between nations that could protect them from the well-known dangers brought about by nationalism: "America ... [will lead] through internationalism rather than through nationalism, through the attempt to realize a family of nations with a common, supra-national government rather than through the attempt to become itself a dominant nation." ${ }^{59}$

In Russell's opinion, the viability of transnationalism was precisely demonstrated by artistic communities, given the way they distinguished and divided people in relation to ideas and occupations, rather than geographical location or nationality. ${ }^{60}$ As a point in fact, The Seven Arts is the site where the magazine-community seems to take firmer ground as the microcosm of the reimagined (trans)national community. Nationalism was nevertheless still present, even if under a different cover: "It is in nationality today that the race finds that larger self to which the individual may give all and so become human and high. The dream of vague internationalism that loosely caught the imagination a decade ago is gone ... To make the coming inter-nation we need nations," argued James Oppenheim. ${ }^{61}$

Regarding the Portuguese case, Orpheu was indeed a ground for experimentation regarding new forms of individual feeling and their relation to nonnational influences. This "little" magazine was the space where the aesthetic concepts outlined by Fernando Pessoa-from paùlismo (paulism) to 
interseccionismo (intersectionism) and sensacionismo (sensationism)—gained form and visibility. Pessoa attempted to link both to the nation's cultural reform and its mission. The new aesthetics caused public outrage, thus confirming its divergence from conventional cultural discourse. Indeed, Pessoa's aesthetics should be understood under the light of the future endeavors the poet projected onto the Portuguese nation, namely restoring its influence as a world power, even if the stage, the means, or the form were no longer the same.

Paulism was the enactment of a new style, "vague, subtle, and complex," previously submitted by Pessoa in the literary magazine A Aguia. The idea behind both paulism and intersectionism was an aesthetics of instability that reflected the influence of cubism and futurism in drawing intersections of diverse pieces, as shown in "Chuva Oblíqua" ("Slanting Rain"), published in Orpheu 2. hese concepts, new and complementary, would fulfill in poetry what Pess a vaw as a calling to this new culture: universality, or impact beyond national borders. Whereas intersectionism suggested the breaking of the unities of time and space, as of the subject's body, sensationism individualized each fragment. Sensationism ultimately validated the "feel everything" ("sentir tudo") that Pessoa had defined as an essentially Portuguese form of identification. Once the call to feel everything in every possible way (as Pessoa/Campos had put it, in the "Triumphal Ode," in Orpheu 2) had been updated, ${ }^{63}$ the process would be completed by spreading Portuguese individuality beyond borders. This dissemination would resort to the spiritual (that is, cultural) imperialism of what Pessoa defined in Mensagem as the Fifth Empire, a worldwide spiritual enterprise.

Pessoa defined Portuguese sensationism as the act of reducing other cultures to the self's own sensations, that is, converting the "other" into the "self," a definition that brings to mind ideas the cultural cannibalists would later champion to renew Brazilian culture. Following Pessoa/Álvaro de Campos, sensationism was the "intellectualization of processes" through "our sensations of things." ${ }^{64}$ It defined Portuguese identity as a process that constructed, absorbed, and remade the "other," based on the belief that Portugal's denationalization, caused by a noncritical acceptance of foreign models and patterns, had created an identity space that was rich, but deformed, able to contain every nationality, but lacking order. It was therefore a nonidentity-a heterogeneous field where multiple combinations could be tested.

Hence Pessoa/Álvaro de Campos's words, in a poem intended for Orpheu 3 (the issue that was organized but never published due to lack of financial support): "Eu . . . . . / que acho que não faz mal não ligar à pátria / Porque não tenho raiz, como uma árvore, e portanto não tenho raiz ...” (I 
... / . . / who think[] it's fine not to feel too attached to his homeland / For I don't have roots, I'm not a tree, and so I have no roots . . .). ${ }^{65}$ Rather than an anti-nationality, the issue here at stake was transnationality. Being Portuguese meant being open and having choices: being rootless. Being Portuguese meant being able to benefit from every contact and to dwell in every nationality. It was another way to devise the transnational identity also envisioned by the The Seven Arts contributors.

Like the community at The Seven Arts, who attacked traditional individualism, Fernando Pessoa set out to seek an alternative, without overlooking the need to connect the individual and the community. Taking individualism as one of the prejudices instilled by Christian morality, Pessoa/Álvaro de Campos announced the "abolição do preconceito da individualidade" (abolition of the preconception of individuality) as the second phase of the necessary “intervenção cirurgica anti-cristã” (anti-Christian surgical intervention). In addition to naming the problems affecting the modern world, namely Portuguese culture and society, Pessoa/Álvaro de Campos's "Ultimatum," in Portugal Futurista, called for a "cirurgia sociologica" (sociological surgery). The process was meant to abolish different forms of dogma, including that of "individualidade artística" ${ }^{66}$ (artistic individuality). ${ }^{67}$ Yet, only poets were capable of taking that outside-inside step, as it were, incorporating the community while maintaining their individual identity, their expression no longer being individual or communal, but rather an interexpression.

The stage of "adaptação artificial" (artificial adaptation) would follow, consisting of "a transformação violenta da sensibilidade de modo a tornar-se apta a acompanhar,... (D) progressão dos seus estimulos" (a violent transformation of sensibility so that it can keep pace ... with the progress of its stimuli) ${ }^{68}$ This idea implied a basic philosophical condition that might also explain the remaining implications: "a maior verdade será a soma-sínteseinterior do maior número de opiniões verdadeiras, que se contradizem umas às outras" (the greatest truth will be the inner-synthesis-summation of the greatest number of true opinions that contradict one another). ${ }^{69} \mathrm{This}$ principle contemplated the coexistence of differences (the "contradictions") rather than their obliteration, representing a great opportunity for Pessoa's identity theory. Notwithstanding, Pessoa/Campos added that this quality would eventually harmonize differences when stating that the individual-to-come, the "Superman," would be "não o mais livre, mas o mais harmónico!"70 (not ... the freest of all men, but the most harmonious!). ${ }^{7}$

Brazilian modernists imagined the ground zero or new beginning of national culture as the "Matriarcado de Pindorama" (Pindorama's Matriarchy). Founded by the "Revolução Caraíba" (Caribbean Revolution), 
Pindorama's matriarchy was an alternative to colonial patriarchy. This identity was filled with possibilities, as those redefined in the Portuguese and the U.S. "little" magazines, and elaborated by Oswald de Andrade as "[the] undated world. Unsigned," ("Manifesto Antropófago" ["Cannibalist Manifesto"]) in a manifesto that officially inaugurated the so-called second Brazilian modernism and the "little" magazine Revista de Antropofagia, in 1928.

After the explosion of academicism brought about by Klaxon in the earlier I920s, cultural cannibalism followed a logic of correction and rewriting, suggesting the restoration of the Brazilian territory prior to colonization, thus clearly inaugurating a postcolonial critique. Revista de Antropofagia was a manifesto-magazine, much like Portugal Futurista: it called on every enlightened citizen involved in cultural creation to "eat everything anew" and reproduce it according to the originality, simplicity, and naïvety that were said to characterize indigenous peoples. Guided by the motto "Vamos comer tudo de novo" (Let's eat everything once again), ${ }^{72}$ the movement put forth a new cultural model, in which "meat" meant "the idea," and the metaphorical ingestion of the "other" worked on a transindividual level. ${ }^{73}$

By affirming the relevance of the national project in this endeavor, cultural devouring stood as a synonym for absorbing other cultural influences and nationalizing them so as to convert them into products capable of strengthening the national self. Cultural anthropophagy was therefore a kind of compensating process that also favored the cohesion of the community: "Antropofagia é a comunhão da carne .. . É um movimento do 'Homem' nacionalizando tudo aquilo que a 'terra' ainda não tinha podido nacionalizar" (Anthropophagy is the communion of the flesh ... it is a movement of t(Man," nationalizing everything that the "land" has not been able to nationalize), as summarized by contributor Clovis de Gusmão. ${ }^{74}$

Cultural anthropophagy completed the refinement process set forth by another of Oswald de Andrade's manifestos, "Manifesto da Poesia PauBrasil" ("Brazilwood poetry Manifesto"), published in I924, in the Rio de Janeiro newspaper Correio da Manhã. The name Brazilwood referred to a tree whose wood and red resin were highly priced in European markets during the imperial epoch and were exported from the colony by the Portuguese. Deepening cultural anthropophagy in terms of content, Oswald's "Brazilwood" aesthetics attempted to refine language and invert the colonialist exchange by creating a culturally (and not just materially) valuable export product. Thus, cultural cannibalism consisted on "um trabalho de deglutinação, dos ídolos falsos que vivem no nosso aparelho intelectual" (the task of swallowing the fake idols that live in our intellectual system). ${ }^{75}$ 
Its dynamics worked at two levels: on the one hand, it absorbed the foreign and the negative by eliminating the enemy: "[a] mentalidade inútil, esteril, improdutiva" (the useless mentality, sterile, unproductivi ${ }^{\text {n the }}$ other hand, what might otherwise be opposite became compat since what was once different/other was now part of the self and empowered it. The "mentalidade inútil" (useless mentality) was thus regenerated by being implanted "na mentalidade dos novos, dos arrojados, dos viris, dos que tem o anseio das grandes renovações sociaes" (into the mentality of the young, the bold, the virile, those who yearn great social renewal). ${ }^{76} \mathrm{I}$ believe the process points to the fusion and harmonization underlying both the Portuguese and the U.S. cultural reforms debated in the "little" magazines projects.

The establishment of this cultural operation implied a significant inversion of values. Somewhat like the elaboration of primitivism at The Seven Arts, cultural cannibalism explored particular belittling features usually ascribed to Brazilian identity - innocence, primitivism, naïvety-which constituted the stereotype of the "other" imposed by colonialist discourse, aiming at reversing them. In this sense, the goal of Revista de Antropofagia was to restore the happiness and enthusiasm once stolen by the colonizers- "a história do homem no Brasil é mal contada desde a carta de Vazcaminha" (the history of Brazil has been mistold since Vazcaminha's letter) ${ }^{77}$ - by resorting to parody, irony, and humor, in order to desacralize the highlights of pedagogical discourse, that is, nationalist history.

The Indian cannibal became the subject of this new narrative, the native free from the definitions and associations imposed by colonialism. The native cannibal thus became a new type of hero, offering a blank identity to be filled in by the cannibalist intellectuals who refused classical definitions: this new protagonist of a revised history was a mischievous, despicable, and humiliated (anti-)hero. He was aware of his smallness but also able to subvert any rule and invent new standards, including heroism itself. In effect, he ultimately succeeded in his endeavors by resorting to mischief and popular wisdom.

The profoundly critical subversion presented by cultural cannibalism was a way to regenerate the process of cultural exchange; yet, rules were now dictated by the colonized, setting forth new cultural connections whose focal point was the colonized themselves. Invoking the principle of inversion as played in Carnival, the national festival, Oswald de Andrade defined the new identity as one of constant mutability. A deeply hybrid space, full of diversity and contradiction, thus emerged as the basis for a renewed Brazilian identity. The cultural cannibals were, in this sense, endowed with a performative ability that enabled them to resist and to challenge the pedagogical master narrative of the nation. 


\section{Conclusion}

The "little" magazines emerged from the need to instate alternative forms of subjectivity and aesthetics. They became the fora in which their contributors experimented with aesthetic and cultural models that proved more adequate to the national sensibility and social reality. As a guarantee of humanity, individuality gave artists the power to represent their nations at a time when individuality was increasingly threatened by forms of standardization inherent both in mass culture and in the pedagogical discourse of the State.

Although the transcendence of the national model remained as the target of these projects, building the nation was understood as a requirement for the creation of the future transnation. That is why the nation building process proposed in these projects was fundamentally related to the magazine contributors' belief in the ability of each nation to keep up with progress and partake in modernization. ${ }^{78}$ The nation did remain as a vital stage of and necessary condition for the coming into being of the transnation. For this reason, I address the forms of nationalism developed by the artists and intellectuals in case as emancipatory, regardless of their flaws from a contemporary perspective.

If we then consider the "little" magazines as laboratories where the transnational model is tested, as I have suggested, then their contributors-that is, their citizens - and also their criteria for selecting contributors, stand as a symbol for the ideals here discussed. In addition, it is important to recall the idea of the magazines as spaces, as noted by David Bennett, but spaces that are unstable at heart, given the fragmentary and provisional character of both the materials they publish and the ideas they bring to light. The "little" magazines emerge as discontinuous territories that are exempt from the constraints of sequential logic, so that their readers are also free to start reading from any point, switch in-between articles, intersperse the reading, turn back or read further ahead, a mobility that is manifestly impossible in a literary item such as the book. ${ }^{79}$

Clara Rocha underscores this idea when referring to literary magazines as "places of collective affirmation." In fact, whenever a project would come to an end, the same community of intellectuals and artists would reunite in order to reactivate it in a new publication. ${ }^{80}$ This was the case of Orpheu giving way to Portugal Futurista; The Seven Arts, to The Nerw Republic; and Klaxon saw its intellectual community reinvent itself in Revista de Antropofagia, after contributions to Terra Roxa e Outras Terras (São Paulo, I926). Despite this forced mobility imposed by the short lifespan of "little" magazines, there was 
a degree of continuity in the projects and permanence in their communities which allows one to perceive the coherence of their projects, even if location, or territoriality, was neither a given nor a need.

A final word regarding unresolved tensions. The inner life of the magazines showed that, although the absence of conventions, the primacy of individual freedom, and diversity were repeatedly celebrated by their contributors, the forging of these communities was not random and it certainly did not vary according to personal wishes. Modeled after the groups who organized and contributed to them, they had in mind the formation of cultural elites, or a spiritual aristocracy, in Fernando Pessoa's words, which was expected to occupy the uninhabited minds of nations. These cultural elites perceived themselves as alternatives to the idea of the nation as a political and social construct alone, as Almada Negreiros remarked. ${ }^{81}$ Yet, the exclusiveness of these communities was quite evident, demonstrating the contradictions that their contributors never knew how or wanted to solve. After all, contributing to the ideological framework of the magazine was not open to any man, let alone to any woman. The extremely scarce number of female contributors to these magazine-nations, whose intention was to mirror a social formation to come, is striking; the same could be said of racial diversity. And, in the end, the transnational design the magazines rehearsed did not win over, either.

If "little" magazines are, as Malcolm Bradbury has suggested, "ephemeral, episodic, unreliable, always suffering phoenix-like deaths and rebirths," the national model they questioned has remained incomparably firmer and long-lasting. Which is not to say that the "little" magazines were a failure; for reading through them gives us the backstage of culture, the live display of vibrant polyphonic debates about the making and remaking of the meanings of national identities, and also alternatives to them. They are all a part of what Suzanne Churchill and Adam McKible aptly called "the large conversation that became modernism." ${ }^{3}$

MARIA JOSÉ FLORENTINO MENDES CANEL $\rightarrow$ an assistant professor in the Faculty of Letters and a Researcher at the focial Studies at the University of Coimbra, Portugal.

Notes

The publication of this text was supported by Fundação para a Ciência e a Tecnologia, under the Strategic Project (UID/SOC/50012/2013).

I. José de Almada Negreiros, "Fernando Pessoa O Poeta Português," in Ensaios-Obra completa, vol. 5, introd. by Eduardo Lourenço. (Lisbon: Imprensa Nacional-Casa da Moeda, 
I992), I39. Unless indicated otherwise, translations from Portuguese and Brazilian texts are the responsibility of the author of this essay.

2. José de Almada Negreiros, "Prometeu," in Ensaios-Obra completa, vol. 5, introd. by Eduardo Lourenço. (Lisbon: Imprensa Nacional-Casa da Moeda, I992), ıo6.

3. Homi Bhabha, Nation and Narration (London: Routledge, I990), 297.

4. Robert Scholes, "Afterword: Small Magazines, Large Ones, and Those In-Between," in Little Magazines E Modernism. New Approaches, ed. Suzanne W. Churchill and Adam McKible (London and New York: Routledge, 2007), 217.

5. Suzanne W. Churchill and Adam McKible, "Introduction," in Little Magazines E Modernism. New Approaches, ed. Suzanne W. Churchill and Adam McKible (London and New York: Routledge, 2007), 9.

6. Benedict Anderson, Imagined Communities: Reflections on the Origin and Spread of Nationalism (London: Verso, I983), 3I.

7. Edward Bishop, "Re-Covering Modernism-Format and Function in the Little Magazines." in Modernist Writers and the Marketplace, ed. Ian Willison, Warwick Gould, and Warren Chernaik (London: Macmillan, 1996), 287.

8. Eric Bulson, Little Magazine, World Form (New York: Columbia University Press, 20I7), 3 . 9. Ibid., II.

Io. Sandhya Shukla and Heidi Tinsman, "Introduction: Across the Americas," in Imagining Our Americas: Toward a Transnational Frame, ed. Sandhya Shukla et Purham: Duke University Press, 2007), 2.

II. Shelley Fisher Fishkin, "Crossroads of Culture: The Transnational Turn in American Studies-Presidential Address to the American Studies Association, November I2, 2004," American Quarterly 57, no. I (2005): 2I.

I2. Ibid., 24 .

I3. Winfried Fluck, "A New Beginning? Transnationalisms," New Literary History 42 (20II): 366.

I4. Immanuel Wallerstein, The Modern World System: Capitalist Agriculture and the Origins of the European World-Economy in the Sixteenth Century (New York: Academic Press, 1976), 23I. I993) 15. . entura de Sousa Santos, ed., Portugal: um retrato singular (Oporto: Afrontamento,

I6. 2 t versions of all magazine editions were the basis of this study, as of all citations. When quoted, longer titles-Portugal Futurista, Revista de Antropofagia and The Seven Arts-will hereafter be abbreviated as $P F, R A$, and TSA, respectively, and cited by number/ volume, date and page number. Digital versions, except for Portugal Futurista, are available as well: Klaxon Mensário de arte moderna $\mathrm{n}^{\circ}$ s I-9 (May I922-Jan. I923). Facs. Ed. (São Paulo: Livraria Martins Ed., I972), Scribd: https://pt.scribd.com/ document/342853025/ KLAXON-NO-I-pdf; Orpheu (I9I5) Facs. Ed. (Lisbon: Ática, I984), Scribd: https://pt.scribd. com/doc/67991299/Revista-Orpheu-N\%C2\%BA-I-pdf-rev; Revista de Antropofagia (May 1928-Aug. I929). Facs. Ed. (São Paulo: Cia. Lit. Ypiranga, I976), Scribd: https://pt.scribd. com/document/164418325/Revista-de-Antropofagia-ano-I-n-o5-set-I928-pdf; The Seven Arts (Nov. I9I6-Oct. I9I7) Facs. ed. 2 vols. (New York: AMS Reprints, s.d.), Modernist Journals Project: accessed November II, 20I7, http://library.brown.edu/cds/mjp/render. php?view=mjp_object\&id=SevenArtsCollection.

I7. José de Almada Negreiros, Textos de intervenção-Obra completa, vol. 6 (Lisboa: Imprensa Nacional-Casa da Moeda, I993), 23.

18. João Medina, “Ob! A República! ... ": Estudos sobre o republicanismo e a Primeira República Portuguesa (Lisbon: Instituto Nacional de Investigação Científica, 1990).

I9. Almada Negreiros, "Fernando Pessoa O Poeta Português," Ensaios, I39.

2o. Fernando Pessoa, Ultimatum e Páginas de Sociologia Política, ed. Joel Serrão (Lisboa: Ática, I980), I32.

2I. Fernando Pessoa, Mensagem (Lisbon: Parceria António Maria Pereira, I934).

22. Irene Ramalho Santos, Atlantic Poets: Fernando Pessoa's Turn in Anglo-American Modernism (Hanover and London: University Press of New England, 2003) 
23. Qtd. in Mário da Silva Brito, "O Alegre Combate de Klaxon" [Kaxon's Joyful Combat], Introduction to Klaxon's Facs., 6th ed. (S. Paulo: Livraria Martins, I972). Translation by the author; all translations from the Brazilian "little" magazines are by the author.

24. Maria Irene Ramalho de Sousa Santos, “A poesia e o sistema mundial," in Portugal: um retrato singular, ed. Boaventura de Sousa Santos (Oporto: Afrontamento, I993), Ioo.

25. $T S A$ 2, no. 4 (Aug. I9I7): 424.

26. $T S A$ 2, no. 5 (Sept. I9I7): 544 .

27. TSA 2, no. 6 (Oct. I9I7): 691-92.

28. $T S A$ 2, no. 4 (Aug. I9I7): 424.

29. TSA 2, no. 4 (Sept. I9I7)

30. TSA I, no. I (Nov. I916):

3I. Romain Rolland, $T S A$ I, no. I (Nov. I9I6): 50.

32. $P F$ (I9I7): 34 .

33. $P F, 34$

34. Richar 2 hith, trans., The Selected Prose of Fernando Pessoa (New York: Grove Press, 2002),

35. Va 2 ck Brooks, TSA I, no. 5 (Mar. 1917): 544 .

36. $T S A$ 2, no. 6 (Oct. I9I7): 698.

37. Ibid., 700 .

38. $P F, 33$.

39. Zenith, The Selected Prose, 83 .

40. Ibid., 34

4I. Zenith, 2 elected Prose, 85.

42. Oppenheim, TSA I, no. I (Nov. r9i6): 53

43. TSA I, no. 3 (Jan. I9I7): 296.

44. TSA I, no. 5 (Mar. I9I7): 535 2

45. TSA I, no. 2 (Dec. I9I6): $154-55$.

46. $T S A$ I, no. 6 (Apr. 1917): 70 I.

47. $T S A$ I, no. 5 (Mar. I9I7): 546.

48. TSA I, no. 2 (Dec. I9I6): I44-5I.

49. Brooks, TSA I, no. 6 (Apr. I9I7): 657 .

50. Oppenheim, $T S A$ I, no. I (Nov. I916): 52.

5I. TSA I, no. 4 (Feb. I9I7): 394.

52. TSA 2, no. I (May I9I7): 108.

53. Ibid., 108-9.

54. TSA I, no. 6 (Apr. I9I7): 639.

55. Almada Negreiros, "Prometeu," Ensaios, ıo6.

56. Almada Negreiros, "Um Aniversário ORPHEU," Ensaios, 6I (italics in original).

57. $T S A$ 2, no. 6 (Oct. I9I7): 680 .

58. Ibid., 68r.

59. Ibid., 684 .

6o. Ibid., 68I, 683 .

6r. $T S A$ i, no. 5 (Mar. I9I7): 505 .

62. "Chuva Oblíqua" ["Slanting Rain"], Fernando Pessoa. Forever Someone Else. Selected Poems, trans. Richard Zenith (Oporto: Assírio e Alvim, 20I3), II5-23 and 238-49.

63. Ibid., I45.

64. Fernando Pessoa, Páginas intimas e de auto-interpretação, ed. and pref. Georg Rudolf Lind and Jacinto do Prado Coelho (Lisbon: Ática, I966), I36-37.

65. Zenith, Fernando Pessoa, I57, I59 (bilingual edition).

66. $P F, 33$.

67. Zenith, The Selected Prose, 84 .

68. $P F, 33$.

69. Ibid., 34 .

70. Ibi

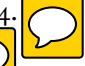




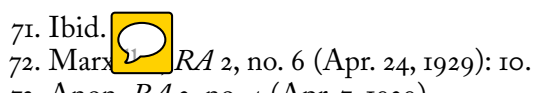

73. Anon, $R A$ 2, no. 4 (Apr. 7, 1929).

74. $R A_{2}$, no. 4 (Apr. 7, 1929).

75. Acquiles vivacqua, $R A$ 2, no. 7 (May I, I929): I2.

76. Isaac Perez, $R A$ 2, no. 6 (Apr. 24, 1929): 1o.

77. João Dornas Filho, $R A$ 2, no. II (June I9, I929): Io.

78. Maria Irene Ramalho de Sousa Santos, "Imperialismo, colonialismo, modernismo e cultura nacional. Portugal e os Estados Unidos no início do século XX," in Intelectuais, Cultura e Sociedade, ed. Maria Irene Ramalho de Sousa Santos et al. (Coimbra: Final Research Report CES/JNICT, I997), 79.

79. David Bennett, "Periodical Fragments and Organic Culture: Modernism, the AvantGarde, and the Little Magazine," Contemporary Literature 30, no. 4 (1989): 480.

8o. Clara Rocha, As revistas literárias do século XX em Portugal (Lisbon: Imprensa NacionalCasa da Moeda, I985), 20.

8I. Almada Negreiros, "Um Aniversário ORPHEU”, Ensaios, 60.

82. Malcolm Bradbury, "Modernism and the magazines," in Malcolm Bradbury: Writer, Critic (Malcolm Bradbury Memorial Trust) accessed November II, 20I7, http://malcolmbradbury. com/criticism_little_magazines.html.

83. Suzanne W. Churchill and Adam McKible, "Introduction," in Little Magazines Eซ Modernism. New Approaches, ed. Suzanne W. Churchill and Adam McKible (London and New York: Routledge, 2007), 5 . 